\title{
Peace-Keeping Costs and Charter Obligations - Implications of the International Court of Justice Decision on Certain Expenses of the United Nations
}

James F. Hogg

William Mitchell College of Law, james.hogg@wmitchell.edu

Publication Information

62 Columbia Law Review 1230 (1962)

\section{Repository Citation}

Hogg, James F., "Peace-Keeping Costs and Charter Obligations - Implications of the International Court of Justice Decision on Certain Expenses of the United Nations" (1962). Faculty Scholarship. Paper 87.

http://open.mitchellhamline.edu/facsch/87 


\title{
Peace-Keeping Costs and Charter Obligations - Implications of the International Court of Justice Decision on Certain Expenses of the United Nations
}

\begin{abstract}
This article analyzes the important legal and political implications of the July 20, 1962 advisory opinion of the International Court of Justice. This opinion dealt with one of the most serious problems facing the United Nations Organization - how to finance and pay for its operations. By a majority of nine to five, the court advised the General Assembly that expenses occasioned by the United Nations operations in the Congo and in the Middle East constituted "expenses to the Organization" within the meaning of Article 17, paragraph 2 of the United Nations Charter. This opinion may prove to be one of the court's most important decisions to date.
\end{abstract}

\section{Keywords}

international court of justice, united nations organization, united nations budget, united nations financing, united nations member contributions, legitimate expenses, voluntary contribution, Congo, Middle East, violation of charter

\section{Disciplines}

International Law 


\section{PEACE-KEEPING COSTS AND CHARTER OBLIGATIONS- IMPLICATIONS OF THE INTERNATIONAL COURT OF JUSTICE DECISION ON CERTAIN EXPENSES OF THE UNITED NATIONS}

\section{JAMES FERGUSSON HOGG*}

On July 20,1962, the International Court of Justice issued an advisory opinion dealing with one of the most serious problems facing the United Nations Organization-how to finance and pay for its operations. ${ }^{1}$ By a majority of nine to five, the court advised the General Assembly that expenses occasioned by the United Nations operations in the Congo and in the Middle East constituted "expenses of the Organization" within the meaning of Article 17, paragraph 2 of the United Nations Charter. ${ }^{2}$ This opinion may prove to be one of the court's most important decisions to date. It is noteworthy that Judge Philip C. Jessup, participating for the first time in a decision of the court, joined in the majority opinion. In an issue honoring Judge Jessup it is therefore fitting to analyze the important legal and political implications of the International Court's opinion.

\section{BACKGROUND}

\section{A. Financial Crisis}

For sixteen years the regular expenses of the Organization have been paid through contributions from the member states. Article 17 of the Charter provides:

1. The General Assembly shall consider and approve the budget of the Organization.

2. The expenses of the Organization shall be borne by the Members as apportioned by the General Assembly. ${ }^{3}$

Since 1946 the General Assembly has allocated these expenses of the Organization on the basis of a formula generally satisfactory to all member

* Professor of Law, University of Minnesota; Visiting Professor of Law, Columbia University.

The author wishes to express his thanks to Professors Wolfgang Friedmann, Louis $B$. Sohn, and Carl Q. Christol, who read this paper in draft and offered many very helpful suggestions, and to the editors of the Columbia Law Review for their many and various contributions.

1. Certain Expenses of the United Nations (Article 17, Paragraph 2, of the Charter), Advisory Opinion, July 20, 1962, [1962] I.C.J. Rep. 151 [hereinafter cited as Orinion]. The court's opinion is reprinted in Hearings on $S .2768$ Before the Honse Committec on Foreign Affairs, 87th Cong., 2d Sess. app. B, at 469 (1962). A synopsis of the opinion is printed in U.N. Rev., Aug. 1962, p. 11.

2. OPINTON 179-80.

3. U.N. Charter art. 17, paras. 1-2. See generally Stoessinger, Financing the UNITED Nations (International Conciliation Pamphlet No. 535, 1961). 
states. 4 That formula has taken into account the relative ability to pay of the various states. ${ }^{5}$ The United States contribution, initially nearly forty per cent of the total cost, has now dropped to approximately thirty-three per cent, while that of the Soviet Union has grown from seven and one-half per cent to seventeen and one-half per cent. ${ }^{6}$

The regular expenses of the United Nations Organization have steadily increased to the point where the annual budget appropriation for 1962 of over $\$ 82,000,000$ is four times greater than that of 1946.7 In addition to increases in the regular appropriation, the Secretary-General is, at the present time, authorized ${ }^{8}$ to incur debts of $\$ 10,000,000$ per month to finance the operations of the United Nations in the Congo (ONUC), designed to help restore responsible government in the Congo, ${ }^{9}$ and $\$ 1,625,000$ per month to finance the United Nations Emergency Force (UNEF), established to help secure and maintain peace between Israel and the surrounding Arab states. ${ }^{10}$

As a consequence of the enormous increase in operational costs, certain states have exhibited various degrees of unwillingness to contribute all or even a part of their share. The real crisis in the United Nations has not been created merely by delinquency in payment, however, but by the position

4. But see Comm. on Contributions, Report, U.N. GeN. Ass. Off. Rec. 16th Sess., Supp. No. 10, at 5 (A/4775) (1962), wherein the Soviet Union's objections to the most recent scale of assessments are noted.

5. For a discussion of the factors taken into account in fixing the scale of contributions see $i d$. at $2-5$.

6. These relative percentages show the assessments of the United States, on the one hand, and of the Soviet Union together with those of Byelorussian S.S.R. and Ukrainian S.S.R., on the other. Because of a compromise in the course of negotiation of the Charter, these two constituent republics of the Soviet Union were admitted to membership in the United Nations in addition to the Soviet Union itself. The percentages gross the assessments for the Soviet Union and the two republics. See U.N. Gen. Ass. Rcs. No. 69 (I), Scale of Contributions to the Budgets of the United Nations for the Financial Years 1946 and 1947 and to the Working Capital Fund, U.N. GEN. Ass. OFF. Rec. 1st Sess., Plenary 131 (A/64/Add. 1) (1947) ; U.N. Gen. Ass. No. 1691 (XVI), Scale of Assessment for the Apportionment of the Expenses of the United Nations, U.N. GEN. Ass. OFF. REc. 16th Sess., Supp. No. 17, at 50 (A/5100) (1962).

7. U.N. Gen. Ass. Res. No. 68 (I), Budgets of the United Nations for Financial Years 1946 and 1947, U.N. GEN. Ass. OFF. Rec. 1st Sess., Plenary 128 (A/64/Add. 1) (1947) ; U.N. Gen. Áss. Res. No. 1734 (XVI), Budget for the Financial Year 1962, U.N. Gen. Ass. Off. Rec. 16th Sess., Supp. No. 17, at 56 (A/5100) (1962).

8. U.N. Gen. Ass. Res. No. 1732 (XVI), United Nations Operations in the Congo: Cost Estimates and Financing, U.N. GEN. Ass. OFF. REc. 16th Sess., Supp. No. 17, at 55 (A/5100) (1962); U.N. Gen. Ass. Res. No. 1733 (XVI), The United Nations Emergency Force: Cost Estimates for Maintenance of the Force, U.N. GEN. Ass. OFF. REc. 16th Sess., Supp. No. 17, at $55(\mathrm{~A} / 5100)$ (1962).

9. See Security Council Resolution Concerning the Situation in the Congo, U.N. SECURITY Councrr. OFF. REc. 15th year, Supp. July-Sept. 1960, at 16 (S/4387) (1960); Written Statement of the United States, p. 131, Financial Obligations of Members of the United Nations (I.C.J. 1962) (Distr. No. 62/21) [hereinafter cited as U.S. WRITTEN STATEMIENT] (cites other resolutions). The factual background of the United Nations in the Congo (ONUC) is summarized in $i d$. at 130-31.

10. U.N. Gen. Ass. Res. No. 1000 (ES-I), U.N. GeN. Ass. OfF. Rec. 1st Envergency Spec. Sess., Supp. No. 1, at 2 (A/3354) (1956). For a summary of the factual background of the creation of the United Nations Envergency Force (UNEF) see U.S. Writren Statement 128-29. Page references to proceedings before the court and written statements in this case are to the preliminary printings and therefore will not correlate with the pagination ultinately used in the permanent volume of Pleadings, Oral Arguments and Documents. 
of some states, most significantly the Soviet Union, that the operations of the United Nations in the Middle East and in the Congo were undertaken in violation of the provisions of the Charter, and that, therefore, the costs attributable to those operations are not legitimate expenses of the Organization. ${ }^{11}$ Accordingly, these states assert that these expenses, which account for nearly two-thirds of the annual budget, are not apportionable among the member states by the General Assembly under article 17(2) and can be met only by voluntary contribution. ${ }^{12}$ It appears that, as of April 30, 1962, twentyeight states, owing approximately twenty-five per cent of the UNEF assessments, had made no payment at all towards the costs of UNEF. ${ }^{13}$ As of the same date, it appears that sixty-three states, owing approximately forty-three per cent of the ONUC assessments, had made no payment to the Congo costs. $^{14}$ In addition to these total defaults, a large number of additional states are in arrears in paying their contributions to these operations. ${ }^{15}$ In an effort

11. See, e.g., Written Statement of the U.S.S.R., p. 5, Financial Obligations of Members of the United Nations (I.C.J. 1962) (Distr. No. 62/21 bis) [hereinafter cited as U.S.S.R. WRITTEN STATEMENT].

12. Sone of these states may be taking the position that there is an affirmative obligation to pay on the part of those members who voted for the resolutions pursuant to which the expenses were incurred.

13. Those states are: Albania, Argentina, Bolivia, Bulgaria, Byelorussian S.S.R., Czechoslovakia, Ethiopia, Greece, Hungary, Jordan, Libya, Paraguay, Poland, Romania, Saudi Arabia, Spain, Sudan, Ukrainian S.S.R., Soviet Union, United Arab Republic (Egypt and Syria), and Yemen. An additional five states-Afghanistan, China, Cuba, Panama, and Peru-have not paid in full the assessments for 1956-1957, let alone the assessments for subsequent years. It appears that the following states, though not members at the date of some earlier assessments for these operations, have as yet made no contribution to assessments subsequent to their admission to membership: Guinea, Cameron, Congo (Brazzaville), Niger, Togo, and Upper Volta. These statistics, and those that follow with respect to contributions toward costs of the ONUC operations, are based on the following documents: Financial Reports and Acconts for the Ycar Ended 31 December 1957 and Reports of the Board of Anditors Thereon, U.N. GEN. Ass. OrF. REC. 13th Sess., Supp. No. 6 (A/3826) (1958); Financial Reports and Accounts for the Year Ended 31 December 1958 and Reports of the Board of Auditors, U.N. Gen. Ass. OrF. REC., 14th Sess., Supp. No. 6 (A/4116) (1959); Financial Report and Acconnts for the Year Ended 31 December 1959 and Reports of the Board of Anditors, U.N. GEN. Ass. OfF. Rec. 15th Sess., Supp. No. 6 (A/4380) (1960) ; Financial Report and Acconnts for the Year Ended 31 December 1960 and Report of the Board of Auditors, U.N. GeN. Ass. OFF. REc. 16th Sess., Supp. No. 6 (A/4777) (1961); and Financial Report and Accounts for the Year Ended 31 December 1961 and Report of the Board of Auditors, U.N. GeN. Ass. OfF. Rec. 17th Sess., Supp. No. 6 (A/5206) (1962); U.N. SEcretariat, Statement on the Collection of Contributions as AT 30 April 1962 (ST/ADM/ SER.B/158) (1962).

14. These states are: Afghamistan, Albania, Argentina, Austria, Belgium, Bolivia, Bulgaria, Byelorussian S.S.R., Cambodia, Chile, China, Colombia, Congo (Brazzaville), Costa Rica, Cuba, Czechoslovakia, Dominican Republic, Ectuador, El Salvador, Ethiopia, France, Ghana, Greece, Guatemala, Guinea, Haiti, Honduras, Hungary, Indonesia, Iraq, Italy, Jordan, Laos, Lebanon, Libya, Mexico, Morocco, Nepal, Nicaragua, Niger, Panama, Paraguay, Peru, Poland, Portugal, Romania, Saudi Arabia, South Africa, Spain, Sudan, Togo, Ukrainian S.S.R., Soviet Union, United Arab Republic (Egypt and Syria), Upper Volta, Uruguay, Venezuela, Yemen, and Yugoslavia. It appears that the following states, though not members at the date of the first assessment for these operations, have as yet made no contribution to the assessment subsequent to their admission to membership: Gabon, Mali, Nigeria, and Somalia.

15. As of April 30,1962, fifty-four states were in arrears in their contributions to the UNEF operations. As of January 1, 1962, sixty-eight states were in arrears in their contributions to the ONUC operations. U.N. SECRETARIAT, STATEMENT ON THE COLLECTION OF CoNtributions AS AT 30 April 1962 (ST/ADM/SER.B/158) (1962). 
to make up this deficit, the United Nations is seeking to float a substantial bond issue. ${ }^{16}$ It is apparent, however, that if a substantial number of states continue to deny their liability for these two operations, the gap between expenses and contributions can only grow wider. Assuming that certain states continue indefinitely to deny their liability for these expenses, either these operations must cease or else they must be financed by a smaller group of states ready to assume and pay voluntarily much more than their agreed proportional share. Even if the operations ceased tomorrow, the deficit already accumulated would pose a substantial financing problem, perhaps similarly dependent on voluntary contributions.

\section{B. The Expanded Role of the General Assembly}

The denial of liability for expenses of UNEF and ONUC operations by states such as the Soviet Union can best be understood in the context of the evolution in function and power of the General Assembly since the creation of the United Nations in 1945. As originally conceived, the Security Council was intended to function as a sort of executive organ, responsible for enforcement measures to secure maintenance of the peace. Mandatory orders to states were to emanate only from this organ, subject to veto by any of the five permanent members. Special agreements were to be entered into with member states, pursuant to article 43, whereby national forces would be made available to the Security Council. While the General Assembly was to be concerned with matters of maintenance of the peace, it was limited to making recommendations for settlement, which were not to be binding upon members. This pattern was clearly described in chapter VII of the Charter; and the exclusive nature of the Security Council's jurisdiction in matters of enforcement was carried back into chapter IV, describing the powers and operation of the General Assembly, in the language of article 11(2):

The General Assembly may discuss any questions relating to the maintenance of international peace and security brought before it by any Member of the United Nations, or by the Security Council, or by a state which is not a Member of the United Nations in accordance with Article 35, paragraph 2, and, except as provided in Article 12, may make recommendations with regard to any such questions to the state or states concerned or to the Security Council or to both. Any such question on zwhich action is necessary shall be referred to the Security Council by the General Assembly either before or after discussion. ${ }^{17}$

16. On December 20, 1961, the General Assembly authorized the issuance of bonds up to $\$ 200,000,000$. U.N. Gen. Ass. Res. No. 1739 (XVI), The United Nations Financial Position and Prospects, U.N. GEN. Ass. OFf. REc. 16th Sess., Supp. No. 17, at 60 (A/5100) (1961). On October 2, 1962, the President signed S. 2768, authorizing the United States to purchase $\$ 100,000,000$ worth of these United Nations bonds. 108 CoNG. REc. D929 (daily ed. Oct. 2, 1962).

17. U.N. Charter art. 11, para. 2. (Emphasis added.) 
No special agreements were concluded and approved by the Security Council and the veto effectively stultified most action therein. Faced with the impasse in that organ, at the instigation of this country, the Uniting for Peace Resolution was adopted in 1950, constituting what might be considered a manifesto by the General Assembly. ${ }^{18}$ That resolution in effect codified the arguments concerning the competence of the General Assembly to make recommendations in matters pertaining to the maintenance of international peace and put on record the intention of the General Assembly to do what it could-including the possibility of recommendations of collective military action-to fill the gap caused by the deadlock in the Security Council.10

The Soviet Union argued vigorously in 1950 that the Uniting for Peace Resolution constituted an arrogation of authority by the General Assembly in violation of the Charter and specifically in violation of the division of competence between the Security Council and the General Assembly. ${ }^{20}$ According to the Soviet view, the General Assembly's competence did not extend to "action," and "action" included recommendation of "action" to member states as well as "action" by and in the name of the United Nations. Although the Soviet Union, desiring an immediate end of the aggression against Egypt, did not oppose in the General Assembly the resolutions establishing UNEF ${ }^{21}$ - a force composed of national units but placed under the United Nations command and financed through the United Nations budget ${ }^{22}$ - they did reserve their position on the legality of the whole undertaking. ${ }^{23}$ Similarly, when the Congo crisis developed, they were, on balance, in favor of doing something to stop Belgian interference and so did not vote against

18. U.N. Gen. Ass. Res. No. 377 (V), Uniting for Peace, U.N. GeN. Ass. Ofr. Rec. 5th Sess., Supp. No. 20, at 10 (A/1775) (1960). In fact, the assumption of the responsibility for maintenance of the peace by the General Assembly could be dated back to 1947 and the provision for the Interim Committee of the General Assembly. At that early stage, the Soviet Umion took the position that the creation of the Committee was an unlawful attempt to interfere with the jurisdiction of the Security Council and refused to participate in the work of that Committee. See Coster, The Interim Committce of the General Asscmbly: An Appraisal, 3 International Organization 444 (1949).

On the significance and validity of the Umiting for Peace Resolution see Andrassy, Uniting for Peacc, 50 AM. J. INT'L L. 563 (1956); Woolsey, The "Uniting for Pcace" Resolution of the United Nations, 45 Aar. J. INT'L L. 129 (1951).

19. It is to be remembered, in passing, that the United Nations action commenced in Korea in 1950 was not founded in or on the Uniting for Peace Resolution; that action was made possible by reason of the absence of the Soviet representative from the Security Council when the critical resolutions were adopted in that Council. He had walked out earlier in the year when the Council refused to unseat the Nationalist Chinese representative and returned shortly after the action commenced in Korea. See Gross, Voting in the Security Council: Abstention From Voting and Absence From Mecting, 60 YALE L.J. 209, 238-44 (1951). The Uniting for Peace Resolution was, in fact, a recognition that the Korean resolutions were atypical and could not be expected in another situation.

20. See, for example, Mr. Vyshinsky's statement in the First Committee. U.N. GEN. Ass. OFF. REC. 5th Sess., 1st Comm. 118-22 (A/C.1/SR.357) (1950).

21. OPINION 70.

22. The costs of the Korean War did not create a budgetary crisis in the United Nations because they were paid through the national budgets of the member states voluntarily supplying military contingents.

23. See Oral Statement of the U.S.S.R., pp. 111-12, Financial Obligations of Members of the United Nations (I.C.J. 1962) (Distr. No. 62/150). 
the resolutions in the Security Council. However, they did abstain on several occasions.

The operations in the Middle East and in the Congo, then, signalled a new type of operation by the United Nations whereby a truly international police or military force was created pursuant to General Assembly and Security Council resolutions under the authority of the Secretary-General. ${ }^{24}$

While there is some difference in the origins of the two forces, ${ }^{25}$ their present operation is being supervised in both cases by the General Assembly and both, therefore, to this extent involve the alleged conflict of jurisdiction between the General Assembly and the Security Council. Moreover, all resolutions pertaining to the financing of both operations have been adopted in the General Assembly.

\section{Submission of the Finance Question to the Court}

The deep-rooted disagreements over the proper function of the General Assembly vis-à-vis maintenance of the peace culminated in the problem of financing the ONUC and UNEF military operations. The problem became especially acute with the creation of ONUC, although discussion of which states should pay for the cost and in what amounts began in 1956 and has continued regularly thereafter. In 1959, a special Working Group of Fifteen was appointed by the General Assembly to study the problem and make recommendations. ${ }^{28}$ This group reported that they could not find a sufficiently large area of agreement upon which to make recommendations to the General Assembly.27 In the course of considering the group's report, the Fifth Committee made and adopted a proposal to seek the opinion of the International Court on whether the expenses of these two operations were "expenses of

24. For a discussion of the legal issues involved in the creation and maintenance of the United Nations forces under the authority of the General Assembly see Comm. on Study of Legal Problems of the United Nations, Report, 51 AMERICAN Soc'y INTERnatronal L. Proceedings 205 (1957); Miller, Legal Aspects of the United Nations Action in the Congo, 55 AMr. J. INT'工 L. 229 (1958); Sohn, The Anthority of the United Nations To Establish and Maintain a Permanent United Nations Force, AM. J. INT'L L. 229 (1958); Woolsey, supra note 18.

25. In the case of the UNEF operations, the force was conceived and managed pursuant to resolutions of the General Assembly alone. In the case of the ONUC operations, the original resolutions pursuant to which the force was organized were adopted in the Security Council in July and August of 1960. In September, however, any possibility of accord between the Soviet position and that of other major powers in the Council disappeared. As a result, purstuant to the Uniting for Peace Resolution, the Council called an emergency session of the General Assembly. A subsequent resolution of the General Assembly reaffirmed the resolutions of the Security Council and requested the Secretary-General to continue operations. Henceforth, the ONUC operations were under the supervision of the General Assembly.

26. U.N. Gen. Ass. Res. No. 1620 (XV), Examination of the Administrative and Budgetary Procedures of the United Nations, U.N. GEN. Ass. OFf. REc. 15th Sess., Supp. No. 16A, at 14-15 (A/4684/Add. 1) (1961).

27. Working Group of Fifteen, Report on the Examination of the Administrative and Budgetary Procedures of the United Nations, U.N. GEN. Ass. OFF. REc. 16th Sess., Annexes, Agenda Item No. 62, at 6 (A/4971) (1961). 
the Organization" within the meaning of article $17(2)$ of the Charter. ${ }^{28}$ The General Assembly subsequently adopted the proposal of the Fifth Committee to refer the question to the court. ${ }^{29}$

Underlying the phrasing of the question was the desire to get a ruling on whether the expenses of these operations were apportionable by the General Assembly under article 17(2) and must be borne by the member states as apportioned. It seems clear that two purposes thought to be served by getting an affirmative opinion would be the encouragement of payment by states in arrears and the creation of further pressure on the Soviet Union and the other states arguing the invalidity of these expenses. ${ }^{30}$ The French delegate introduced a draft amendment at the Plenary Session that would have expressly requested the court to investigate and pass on whether the expenditures relating to these operations had been decided on in conformity with the provisions of the Charter. ${ }^{31}$ The amendment's defeat left unclear the precise intention of the General Assembly in its phrasing of the question. But for this French proposal, it might have been assumed that the resolution contemplated investigation by the court of the validity of the resolutions and action pursuant to them as a condition precedent to passing on the question whether the expenses incurred were "expenses of the Organization." It was subsequently argued, however, that the rejection was intended to indicate the Assembly's intention that the court not investigate the validity of the relevant resolutions. ${ }^{32}$

\section{The Court's Opinion}

The initial problem, not uncommon with requests for advisory opinions of the court, was interpretation of the question posed by the General Assembly. Some disagreement developed on the court as to whether the General Assem-

28. U.N. Gen. Ass. Off. Rec. 16th Sess., Annexes, Agenda Item No. 62, at 13, 16 (A/5062) (1961).

29. U.N. Gen. Ass. Res. No. 1731 (XVI), Administrative and Budgetary Procedures of the United Nations, U.N. GeN. Ass. OfF. Rec. 16th Sess., Supp. No. 17A (A/5100) (1961).

30. Thus, during discussion in the General Assembly of the proposal to get an advisory opinion from the court, the Soviet representative said: "The proposal to ask the International Court of Justice to issue an advisory opinion is merely an attempt in this case to find the means for exerting pressure on those States which on very good grounds-on political and juridical grounds-do not feel that it is possible for them to participate in the financing of operations such as the maintenance of the Emergency Force in the Middle East or the United Congo Operation." U.N. Gen. Ass. OFf. Rec. 16th Sess., Plenary 61 (A/PV.1086) (1961).

31. See U.N. Gen. Ass. OFF. Rec., 16th Sess., Annexes, Agenda Item No. 62, at 16 (A/L.378) (1961) ; U.N. GeN. Ass. Off. Rec. 16th Sess., Plenary 57 (A/PV.1086) (1961).

32. See $i d$. at 62 (explanations of negative vote of the United Kingdom). Mr. Price, explaining the negative vote of Canada, said: "It would therefore be invidious for this Assembly to go to the Court and put into question a large number of its own decisions taken over a number of years." Id. at 63-65. Mr. Klutznick, explaining the negative vote of the United States, left some ambiguity over whether the court was to be precluded from an investigation of the validity of the resolutions in question. Id. at 66-70. 
bly had intended the court to assume the validity or, to use Judge Koretsky's word, "charterability" of the resolutions authorizing and maintaining the operations in the Congo and Middle East. Regardless of the General Assembly's rejection of the French draft amendment, the opinion of the court concluded $\mathrm{d}^{33}$ that an investigation of the validity of the resolutions involved was appropriate before the expenses could be characterized as "expenses of the Organization."34

The authors of the majority opinion carefully pointed out, however, that three questions might have been put arising out of the language of article 17(2) but that the Assembly had inquired only as to the first of them. The opinion purported to be limited strictly to characterization of the expenses and expressed no view on the other two potential questions concerning interpretation of article 17(2) - the validity of the Assembly's apportionment of the expenses, and the meaning and implication of the further phrase in article $17(2)$, "borne by the members." 35 The significance of this limitation on future debate in the General Assembly will be considered later. ${ }^{36}$ At this point it may be noted that, potentially, one way to bring pressure on member states refusing to contribute and in arrears would be to invoke the sanction in article 19. Under that article, a state more than two years in arrears in its contributions shall have no vote in the General Assembly. ${ }^{37}$ By indicating that two further legal issues would have to be considered before any such consequence might follow, the court appears to imply that its decision does not, inexorably, indicate the existence of a case for suspension determined merely by the mathematical computation of whether a member is in arrears to the extent of a two-year period.

The major point of disagreement between the majority of the court and most dissenters was the validity and legitimacy of the two peace-keeping operations. The approval given to them by the court opinion constitutes,

33. The majority opinion speaks for Vice-President Alfaro and Judges Badawi, Wellington Koo, Tanaka, and Jessup. Judge Spiropoulos made a declaration indicating acceptance of the court's conclusion but disagreement with some of the views contained in the court opinion. Concurring opinions were given by Judges Fitzmaurice, Morelli, and Spender. Dissenting opinions were given by President Winiarski and Judges Basdevant, Moreno Quintana, Koretsky, and Bustamante y Rivero. See OpINIoN 179-81.

34. See, e.g., id. at 157, 163-65, 167, 177.

The question whether validity of the resolutions was necessarily before the court had considerable significance in both concurring and dissenting opinions. See text accompanying notes 46-57 infra.

35. "The question put to the Court has to do with a moment logically anterior to apportionment, just as a question of apportionment would be anterior to a question of Members' obligation to pay.... If the Court finds that the indicated expenditures are such 'expenses', it is not called upon to consider the manner in which, or the scale by which, they may be apportioned." OPINION 158.

36. See notes 49 \& 50 infra and accompanying text.

37. Article 19 of the Charter provides: "A Member of the United Nations which is in arrears in the payment of its financial contributions to the Organization shall have no vote in the General Assembly if the amount of its arrcars equals or exceeds the amount of the contributions due from it for the preceding two full ycars. The General Assembly may, nevertheless, permit such a Member to vote if it is satisfied that the failure to pay is due to conditions beyond the control of the Member." 
then, for the first time, express judicial approval of the practical transfer of responsibility for maintenance of peace from the Security Council to the General Assembly.

\section{A. The Majority Opinion}

The majority opinion first deals with the question whether the phrase "expenses of the Organization," within the meaning of article $17(2)$, is impliedly qualified by the words "regular" or "administrative."38 Applying appropriate techniques for treaty interpretation, the majority concluded that article 17(2) refers to "expenses" incurred by the Organization in furtherance of one of the purposes of the United Nations. ${ }^{39}$ Referring to the first listed purpose in article 1-maintenance of international peace and securitythe majority demonstrated that the operations in question were in execution of the purposes of the United Nations, and even suggested that the opinion might stop with this finding. ${ }^{40}$

The majority also considered, however, whether the General Assembly's budgetary authority might impliedly be limited by reason of the alleged exclusive authority of the Security Council in matters of maintenance of peace; the court reasoned that such a limitation "in turn might limit the meaning of 'expenses'" in article $17(2) .41$ In this way, the majority took up the issue central to the Assembly debates and the Soviet objections. In terms of constitutional doctrine, the majority's analysis of this issue is the major contribution of the opinion. The majority first cited article 24 and its statement that the Security Council has only primary responsibility for the maintenance of international peace and security. ${ }^{42}$ Next, the power of the General Assembly to recommend measures, set out in article 14 and in the language of article 10, was found to give the General Assembly a wide mandate in the area of maintenance of peace. In effect, the majority took the position that with respect to maintaining peace the General Assembly was authorized to do anything that the United Nations could do unless there was a specific prohibition..$^{43}$ Such a prohibition was clear in article 12. Without a request from the Security Council, the General Assembly could not make recommendations concerning any dispute or situation in relation to which the Security Council was exercising its functions. Another equally clear prohibition contained in article 11(2) was that, where "action" was required on any such question, the General Assembly must look to the Security Council. As expounded in the majority opinion, the scope of this latter prohibition was limited-"action" was interpreted to mean "such action as is solely within

38. OpInIon 159-61.

39. Id. at 158,167 .

40. Id. at 167-70.

41. Id. at 162 .

42. Id. at 163 .

43. Id. at 162-64. 
the province of the Security Council," that is to say, enforcement measures imposed under chapter VII of the Charter. ${ }^{44}$ The majority then found-that the UNEF and ONUC operations were not enforcement actions within the meaning of that definition and chapter VII. ${ }^{45}$

Accordingly, the majority concluded that the cost:- of the ONUC and UNEF operations were expenses which the General Assembly, under article 17(2), was entitled to apportion among the member states. ${ }^{46}$

\section{B. The Concurring Opinions}

The majority opinion speaks for five judges. Judge Spiropoulos added an explanatory "declaration" and Judges Spender, Fitzmaurice, and Morelli filed concurring opinions.

Judge Spiropoulos indicated that he could give an affirmative answer on the ground that the costs of the operations were authorized by a vote of two-thirds of the members of the General Assembly and were incurred in the fulfilment of the purposes of the United Nations. For him, however, validity of the resolutions was not in issue because the defeat of the French amendment to the request for the opinion indicated the wish of the Assembly that the court not examine that issue. ${ }^{47}$

Judge Spender likewise found the majority's consideration of validity unnecessary, but for a different reason. To him, a conclusion on the validity

44. Id. at 164-65. The majority opinion states:

The Court considers that the kind of action referred to in Article 11, paragraph 2, is coercive or enforcement action. ... It cannot refer to recommendations which the Security Council might make, as for instance under Article 38, because the General Assembly under Article 11 has a comparable power. The "action" which is solely within the province of the Security Council is that which is indicated by the title of Chapter VII of the Charter, namely "Action with respect to threats to the peace, breaches of the pcace, and acts of aggression".

Id. at $164 \& 165$.

45. Id. at 171, 176-77. It would appear then, that the prohibition found in article 11 is limited to a situation where there is a determination of the existence of a thrcat to the peace, breach of the peace, or act of aggression and of the need for enforcement action ordered against the aggressor.

46. As has been pointed out, see note 35 stupra and accompanying text, the majority opinion carefully delineated the question put: whether these were "expenses." Their apportionment and obligation to pay were said not to be in issue. Nevertheless, the following comment was made:

By Article 17, paragraph 1, the Genetal Assembly is given the power not only to "consider" the budget of the Organization, but also to "approve" it. The decision to "approve" the budget has a close connection with paragraph 2 of Article 17, since thereunder the General Assembly is also given the power to apportion the expenses among the Members and the exercise of the power of apportionment creates the obligation, specifically stated in Article 17, paragraph 2 , of each Member to bear that part of the expenses which is apportioned to it by the General Assembly.

OpINION 164. From this passage it could be argued that the majority did decide that there was a specific obligation to be borne here, validly and presently subsisting in spite of the initial reservation concerning the question put. Perhaps the original reservation was inserted to marshal votes on the court, and for this reason the opinion is less than a resounding response to the question which might have been asked: Is the Soviet Union under a present valid and subsisting obligation to pay the specified portion of the debts already incurred?

47. Id. at $180-81$. 
of the resolutions would not affect the answer to be given to the question submitted to the court. These expenses were of such a character that they could be characterized as incurred in order to give effect to the purposes of the Organization. In these circumstances, in his opinion, the General Assembly determination under article $17(2)$ was conclusive. ${ }^{48}$

Judge Fitzmaurice thought the majority had failed to determine the financial obligations of the member states by limiting the construction of the question to a characterization of the costs as "expenses of the Organization."40 His major reservation related to what he thought was a failure of the majority to indicate the general limitations within which any given expenditure could rank as an "expense of the Organization." In his opinion, prior to a binding apportionment, it must be established that the money spent was an "expense" and that the debt was incurred for a valid and legitimate purpose within the framework of the United Nations. He then developed a dichotomy between obligatory expenses of the United Nations and optional programs "in no way obligatory on it to undertake." The latter were not subject to binding apportionment against states that had not voted for those programs. ${ }^{50}$

Judge Morelli indicated general agreement with the majority on the issue of validity of the resolutions, but, like Judge Spiropoulos, he considered the rejection of the French amendment to be an indication that the court need not consider that issue. ${ }^{51}$

\section{The Dissenting Opinions}

President Winiarski gave primary emphasis in his opinion to his conclusion that no resolution of the General Assembly was binding and that those resolutions apportioning expenses were therefore only recommendations. Perhaps he implied that these resolutions are binding on the states which accepted them. ${ }^{52}$

Judge Koretsky considered the resolutions authorizing the expenses to be invalid and for this reason not apportionable under article $17(2)$. He also considered that the court should not have answered the request since the issue was basically a political rather than a juridical one. ${ }^{53}$

Judge Basdevant dissented on the express ground that, since the French

48. Id. at 182-97 (Spender, J., concurring).

49. See discussion in text accompanying note 35 supra. Said Judge Fitzmaurice, "the Court has taken the view that it is only required to state whether certain specified expenditures are expenses of the Organization, and is not called upon to declare what are the financial obligations of Member States (hence the change in the title of the case)." OPINION 198 (concurring opinion). It is interesting to note the change to which be adverts. The title on the volume of Written Statements is "Financial Obligations of Members of the United Nations (Request for Advisory Opinion)." The title on the court's advisory opinion is "Certain Expenses of the United Nations (Article 17, Para* graph 2, of the Charter), Advisory Opinion of 20 July 1962."

50. OpINron 198-215 (Fitzmaurice, J., concurring).

51. Id. at $216-26$ (Morelli, J., concurring).

52. Id. at 227-34 (Winiarski, Pres., dissenting).

53. Id. at 253-87 (Koretsky, J., dissenting). 
amendment was defeated in the Assembly, the request as framed did not give "'an exact statement of the question upon which an opinion is required"."54 That is to say, he considered that the Assembly had precluded the court from considering the validity of the resolutions authorizing the expenditures, and that the question put could not be answered without considering such validity. ${ }^{55}$

Judge Moreno Quintana dissented because he considered an "appraisement" of conformity of the resolutions with the Charter essential but apparently felt that the Assembly, in rejecting the French amendment, had precluded such appraisement. In the course of his dissent, however, he indicated rather clearly that he considered the operations of both UNEF and ONUC to be enforcement action within the sole prerogative of the Security Council. Applying an unusual construction of the Charter, he suggested that the expenses of enforcement action were the responsibility of the members of the Security Council. ${ }^{56}$

Judge Bustamante y Rivero, who also dissented, found the distinction between simple police or security action and enforcement action a little too subtle. He also believed that the enormous increase in United Nations spending was beyond the bounds originally anticipated by members and hence he doubted whether there was a contractual obligation to pay for these new costs. He concluded that the obligations involved were the responsibility of those states that had explicitly or implicitly accepted the resolutions under consideration. ${ }^{57}$

\section{Analysis of the Court's Reasoning}

\section{A. Reliance on Past Practice of the General Assembly}

The majority opinion possesses an interest beyond the solution of the current problem of the United Nations budget. As a technical, scholarly, judicial opimion, it sums up to date the practice of both the International Court and, before it, the Permanent Court on some aspects of treaty construction. It also gives some new orientation to the science of interpretation of international constitutional documents such as the Charter.

Reiterated on several occasions, with citation to prior opinions, are the ideas, inter alia, that the constructional process requires a reading of the whole instrument in context, the making of a tentative conclusion as to meaning based on such a reading, the testing of that mearing against the purposes which the treaty was designed to serve, and the reference to legislative history. ${ }^{58}$ In technique, except for one dominant facet, the majority opinion,

54. Id. at 235 (Basdevant, J., dissenting).

55. Id. at 235-38.

56. Id. at 239-52 (Moreno Quintana, J., dissenting).

57. Id. at 288-308 (Bustamante y Rivero, J., dissenting).

58. For a discussion of the utilization by the court of this evidence of meaning see Hogg, The International Court: Rules of Treaty Interpretation II, 44 MINN. L. REv, 5, 46-66 (1959). 
and indeed most of the opinions, are orthodox. The somewhat unusual feature of the majority opinion, a feature commented on and criticized in both concurring and dissenting opinions, is the reliance placed on the practices developed in the General Assembly as substantial evidence of the meaning of the Charter. While the majority opinion states that this resort to practice of the General Assembly is not made to find a meaning but only to confirm a meaning found elsewhere, the constant and lengthy resort to that practice may belie the assertion that such reliance is subsidiary. ${ }^{50}$ Reference to the conduct of the parties after they have concluded a treaty, as an aid to construction of their agreement, is not found for the first time in this case. But both Judge Spender and Judge Fitzmaurice, concurring, are highly critical of the majority's reliance on practice approved not unanimously but from time to time by a majority of delegations. ${ }^{60}$ Uniformity of practice or procedure in the General Assembly, supported regularly by a solid majority, does seem entitled to substantial weight in considering the meaning of the Charter. ${ }^{61}$ Such uniformity of practice indicates, or may be taken to indicate by hypothesis, that the states voting in favor of a practice consider it to be consistent with their private construction of the Charter. It tends also to establish or support the reasonableness of the construction advanced. Determination of majority interpretation, however, may provide little help in borderline problem areas in which it is precisely the disagreement of some with

59. The majority opinion, by way of introduction to the reliance on practice in the organization, states:

In interpreting Article 4 of the Charter, the Court was led to consider

"the structure of the Charter" and "the relations established by it between the

General Assembly and the Security Council"; a comparable problem confronts

the Court in the instant inatter. The Court sustained its interpretation of

Article 4 by considering the manner in which the organs concerned "have

consistently interpreted the text" in their practice .... .

OpInion 157. Thereafter, many references are made at every stage of the opinion to the practice followed in both the General Assembly and the Security Council. See, e.g., id. at $159-60,165,171,174$.

60 . Judge Fitzmaurice thought the reliance on practice especially undesirable and unpersuasive because he considered that the inferences drawn by the majority opinion were questionable:

The argument drawn from practice, if taken too far, can be questionbegging. ... In these circumstances, it is hardly possible to infer from the mere fact that Member States pay, that they necessarily admit in all cases a positive legal obligation to do so; and where, as has not infrequently occurred, they have only paid under or after protest, the easier inference is that this was because, for whatever reason (by no means necessarily consciousness of legal obligation) they were unwilling in the last resort to withhold a contribution. Id. at 201 (concurring opinion). See Judge Spender, id. at 185-86, 189, 191-92; President Winiarski, $i d$. at 230-31; Judge Koretsky, id. at 255.

61. Thus, Judge Fitzmaurice-after offering a criticism of the degree of reliance by the majority" opinion, see note 60 supra-continues:

Nevertheless, while the existence of these considerations renders it impossible to regard the practice of the United Nations as conclusive in the matter-(it is indeed the validity of some part of that practice which is put in issue by the present Request) -it cannot be less than very material; and even if a majority vote cannot in the formal sense bind the minority, it can, if consistently exercised in a particular way, suffice to establish a settled practice which a tribunal can usefully and properly take account of.

Id. at 201-02 (concurring opinion). 
the majority practice that occasions the request for an opinion. This form of evidence, if very heavily relied on, would tend to produce an expanded or contracted construction of the Charter depending on the viewpoint at a certain time of two-thirds of the members present and voting. The weakness of such a basis for constitutional interpretation is evident. The court, however, clearly uses the practice of two-thirds of those voting to support its conclusion that the UNEF and ONUC expenses are apportionable under article $17(2)$, despite the substantial number of negative votes cast on that question. ${ }^{62}$

The court's argument from practice, that approval of the undertaking of the UNEF and ONUC operations indicates concurrence by all states in their validity, carries greater weight. Seven basic resolutions, which authorized the Secretary-General to take action, or confirmed action already taken, inevitably involving the incurrence of expense, were adopted either in the General Assembly or Security Council with no negative votes. ${ }^{63}$ References to these resolutions by the majority opinion are phrased in terms of unanimity or absence of negative votes; in fact, actual unanimity was lacking in all but one resolution because of a number of abstentions. ${ }^{64}$

It might be inferred from the majority opinion that a member state is to be taken as having impliedly consented to the validity of a particular resolution by abstaining instead of voting "no"; this new doctrine, if accepted, may be of considerable significance for the practice of abstention in the United Nations. ${ }^{65}$ In the past, delegations have placed many different constructions on an abstention. Clearly, the abstention has been used on numerous occasions when the state called upon to vote considers that its vote should be cast a particular way but, for political reasons or because

62. See, for example, the votes on the following resolutions concerning apportionment, which are among those referred to in the General Assembly's Request for an opinion from the court: Gen. Ass. Res. No. 1441 (XIV), vote in U.N. GEN. Ass. OfF. REC. 14th Sess., Plenary 641 (A/PV.846) (1959) (UNEF; 49 for, 9 against, 21 abstentions); Gen. Ass. Res. No. 1337 (XIII), vote in U.N. GEN. Ass. Off. Rec. 13th Sess., Plenary 598 (A/PV.790) (1958) (UNEF; 42-9-27); Gen. Ass. Res. No. 1089 (XI), vote in U.N. GEN. Ass. OFF. Rec. 11th Sess., Plenary 818 (A/PV.632) (1956) (ONUC; 62-8-7).

63. The resolutions were adopted by the following votes: Gen. Ass. Res. No. 1000 (ES-I), vote in U.N. GEN. Ass. OfF. REc. 1st Emergency Spec. Sess., Plenary 89 (A/PV.565) (1956) (57 for, 0 against, 19 abstentions); Gen. Ass. Res. No. 1001 (ES-I), vote in U.N. GEN. Ass. OFF. REC. 1st Emergency Spec. Sess., Plenary 126 (A/PV.567) (1956) (64-0-12) ; Gen. Ass. Res. No. 1474 (ES-IV), vote in U.N. GEN. Ass. OFr. REc. 4th Emergency 'Spec. Sess., Plenary 102 (A/PV.863) (1960) (70-0-11); Security Council Res. No. S/4383 (renumbered S/4387), vote in U.N. SEcuRITY CoUNCIL OFF. REC. 15th year, 873d meeting 42 (S/PV.873) (1960) (8-0-3; China, France, and United Kingdom abstaining); Security Council Res. No. S/4404 (renumbered S/4405), vote in U.N. Security CouncIL OFF. REC. 15th year, 879th meeting 23 (S/PV.879) (1960) (unanimous without abstentions); Security Council Res. No. S/4426 (renumbered S/4424), vote in U.N. SECuRTYY CoUNCIL OFF. REC. 15th year, 886th meeting 52 (S/PV.886) (1960) (9-0-2; France and Italy abstaining); Security Council Res. No. S/5002, vote in U.N. SECURITY CoUNCIL OFF. REc. 16th year, 982d meeting (S/PV.982) (1961) (9-0-2; France and United Kingdom abstaining).

64. See resolutions cited in note 63 supra.

65. However, in equating, so far as practice is concerned, abstentions with affirmative votes, the majority may cause delegations and foreign ministries to think a little longer about the wisdom of abstaining. See OpINION 230 (Winiarski, Pres., dissenting). 
such a vote would be embarrassing to a political ally, has decided to abstain rather than vote "yes" or "no" outright. In this context, an abstention may be close to an affirmative vote. But to assume that abstention constitutes a commitment to the affirmative of the resolution tends to destroy the very significance of the abstention vote-the fact that it is neither a "yes" nor a "no" vote. 66

Judge Koretsky calls in question the reliance of the majority on the absence of dissent due to abstention on some of the resolutions. The majority, he says, is mistaken in looking only at the votes as cast and ignoring interpretative statements made at the time of the vote to explain the reasons for the way the vote was cast. ${ }^{67}$ Thus, he asserts, in relation to one of the UNEF votes, the Soviet Union preferred a resolution that would call for some intervention in the Middle East even though it reserved its opinion of the validity of the action. ${ }^{68}$ In a number of instances, affirmative votes or abstentions were accompanied by explanations making it fairly clear that some countries, notably the Soviet Union, did not intend their votes to constitute a precedent nor their actions to necessarily reflect their private interpretation of the Charter. Perhaps such disclaimers should be viewed with skepticism when they are not accompanied on critical occasions by effective opposition to alleged ultra vires acts; in discerning the practice of nations, the maxim "actions speak louder than words" may be applicable. And yet, there should be a useful role for abstention in the business of the United Nations when, for example, a state has not reached a definite conclusion on the merits of a resolution or desires to avoid antagonizing friends with whom it disagrees.

On balance, it seems undesirable, as some of the concurring and dissenting judges pointed out, to consider abstention an admission against interest within the well-established doctrine that action consistent with only one particular construction of language in a treaty constitutes such an admission. Particularly, in light of the continuous debate, discussion, and disagreement over financing UNEF and ONUC operations, such votes should

66. Rule 88 of the Rules of Procedure of the General Assembly seems to have relevance here: "For the purpose of these rules, the phrase 'Members present and voting" means Members casting an affirmative or negative vote. Members which abstain from voting are considered as not voting." RULES of PROCEDURE OF THE GENERAL ASSEMDLX, at 16 (A/4700) (U.N. Pub. Sales No. 61.I.4) (1961). For a discussion of the problems of abstention in the Security Council see Gross, Voting in the Security Contncil: $A b$ stention From Voting and Absence From Meetings, 60 YALE L.J. 209 (1951), in which the author appears to conclude that in the Security Council an abstention has been equated with an affirmative vote. Id. at 224 . By way of illustration, consider the following statement made by M. Viand, the representative of France, in explaining the French abstention from the voting on Resolution No. 1583 in the General Assembly: "For these reasons my delegation will abstain when the vote is taken, in the same way as it abstained in the Fifth Committee, and its abstention should be interpreted as a formal reservation regarding the share the French Government might have to carry in the expenditure covered by this resolution." U.N. GEN. Ass. OFF. REc. 15th Sess., Plenary 1499 (vol. 2) (A/PV.960) (1960).

67. Opinion 255, 260 (Koretsky, J., dissenting).

68. Id. at 260 . 
be considered as attempts to reach an ad hoc solution to a specific issue, rather than evidence of Charter interpretation.

\section{B. Interpretation of the Charter in Light of Its Underlying Purpose}

While there are many references in the majority opinion to prior practice of the Assembly, the opinion is not essentially dependent on that support in reaching its conclusion. The key to the majority opinion appears to rest on the stultification of action in the Security Council through the exercise and threat of exercise of the veto and through the failure to conclude agreement to place military forces at the disposal of the Council under article 43. The choice of the majority opinion is recognition of the need to replace the Security Council, when so frustrated, by concerted action through the General Assembly. The problem is one of primacy of values. Which of the following two values should be given pre-eminence in considering the intent of the draftsmen and ratifying governments: that the basic purpose of the United Nations is to attempt to maintain peace and provide a context for the peaceful adjustment of disputes; or that the basic purpose of the United Nations is to maintain a rigid separation of function between the Security Council and the General Assembly? President Winiarski posed the dichotomy very acutely in the following langnage:

The intention of those who drafted [the Charter] ... was clearly to abandon the possibility of useful action rather than to sacrifice the balance of carefully established fields of competence, as can be seen, for example, in the case of the voting in the Security Council. It is only by such procedures, which are clearly defined, that the United Nations can seek to achieve its purposes. It may be that the United Nations is sometimes not in a position to undertake action which would be useful for the maintenance of international peace and security or for one or another of the purposes indicated in Article 1 of the Charter, but that is the way in which the Organization was conceived and brought into being. ${ }^{69}$

Whether one agrees with the President of the court or with the majority seems to depend almost entirely on the selection of the major premise. To the extent that the majority explicitly agree that there are certain clearly and explicitly defined limits on General Assembly authority, they accept the President's approach. ${ }^{70}$ The majority, however, believes that, when the text is to some degree obscure, decision should be consistent with the fundamental purpose of the Union Nations-to attempt, by all means feasible, the maintenance of peace.

Interpreting "expenses" in article $17(2)$, the majority says :

in both cases, it is contended, the qualifying adjective "regular" or "administrative" should be understood to be implied. Since no such

69. Id. at 230 (Winiarski, Pres., dissenting).

70. Thus the majority opinion clearly accepts the continued exclusive prerogative of the Security Council when enforcement action is required. OpINION 164. 
qualification is expressed in the text of the Charter, it could be read in, only if such qualification must necessarily be implied from the provisions of the Charter considered as a whole, or from some particular provision thereof which makes it unavoidable to do so in order to give effect to the Charter. ${ }^{71}$

Clearly, the majority's finding that implied qualifying words are absent from article $17(2)$ is influenced by its major premise concerning the basic purpose of the United Nations. A similar attitude is discernible in the majority's discussion of whether the Charter implies elsewhere, from the division of functions between the General Assembly and the Security Council, a qualification of the former's budgetary authority. The majority's approachassuming no qualification in the absence of positive evidence to the contraryplaces the burden on those who would establish a limitation. The majority, of course, finds no such implication in the Charter:

The provisions of the Charter which distribute functions and powers to the Security Council and to the General Assembly give no support to the view that such distribution excludes from the powers of the General Assembly the power to provide for the financing of measures designed to maintain peace and security. ${ }^{72}$

Perhaps the most persuasive criticism of the majority opinion was made by Judge Bustamante y Rivero, who declared that the majority's distinction between police and enforcement was too subtle-for him the possibility or actuality of use of military forces, to coerce opposing forces, by whomever they may be led or under whose flag they may march, comes within the common meaning of "enforcement." 33 To distinguish police action against individuals or observatory action between states from enforcement action against states may be difficult. But, if the fundamental premise is accepted, the language of the Charter is sufficiently elastic to permit the recognition and acceptance of the majority's construction as plausible and fitting that premise. Thus, the majority opinion and concurring opinions appear to fit comfortably within the scope of accepted judicial interpretation in this country. Moreover, the court's decision is likely to be widely regarded as persuasive because the

71. OpINIon 159. Compare Judge Moreno Quintana's position:

But the least expert mind is inclined to understand that only normal expenses are meant, that is to say those that are indispensable in any organization-in other words, the administrative expenses which are those that could not be dispensed without the organization disappearing. For, if it were not so, and if all the Member States of the United Nations were obliged to bear burdens over and above the responsibility to which they had committed themselves, then the financial power of the Organization would be substituted for the national powers of each of its Members.

Id. at 248 (Moreno Quintana, J., dissenting).

72 . Id. at 164. (Emphasis added.) Notably, the majority does not formulate the proposition as follows: the provisions of the Charter support the view that the distribution of powers includes in the powers of the General Assembly the power to provide for financing such measures.

73. Id. at 295-96 (Bustamente y Rivero, J., dissenting). 
major premise influencing the majority is widely shared by member states in the United Nations, both large and small.

\section{The Authoritativeness of the Decision-Competency in}

\section{CHARTER INTERPRETATION}

The Soviet contention that the General Assembly has acted ultra vires in supporting the UNEF and ONUC operations presents an interesting but certainly not novel issue of jurisdiction. In the United Nations, no agreement has been reached and no custom has developed establishing the ultimate source of power to interpret and apply the Charter. The failure of an attempt made at San Francisco to confer power on the International Court of Justice to conclusively interpret the Charter ${ }^{74}$ is reflected in the lack of obligation of any organ of the United Nations to refer to the court for an opinion on matters of law. Certain organs are authorized to request an advisory opinion of the court ${ }^{75}$ such an opinion, of course, does not bind the requesting organ. The drafters of the Charter, having refused to grant the court exclusive interpretative authority, failed to agree on any substitute for an authentic construction other than by way of ratified amendment to the Charter. ${ }^{76}$

74. See, for instance, the Australian proposals which would have produced this result. Amendments to the Dumbarton Oaks Proposals Submitted on Behalf of Australia, Doc. No. 2/G/14(1), 3 U.N. Conf. INT'L ORG. Docs. 553 (1945).

75. See U.N. C EARTER art. 96.

76. The significant statement emanating from the San Francisco Conference is found in the report of Committee 2 of Commission IV (Judicial Organization). Parts of this statement were cited to the court by states on both sides of the issue. President Wimiarski stressed its signifiance in his dissent. The statement reads:

In the course of the operations from day to day of the various organs of

the Organization, it is inevitable that each organ will interpret such parts of the Charter as are applicable to its particular function. This process is inherent in the functioning of any body which operates under an instrument defining its functions and powers. It will be manifested in the functioning of such a body as the General Assembly, the Security Council, or the International Court of Justice. Accordingly, it is not necessary to include in the Charter a provision either authorizing or approving the normal operation of this principle.

Difficulties may conceivably arise in the event that there should be a difference of opinion among the organs of the Organization concerning the correct interpretation of a provision of the Charter. Thus, two organs may conceivably hold and may express or even act upon different views. Under unitary forms of national government the final determination of such a question may be vested in the highest court or in some other national authority. However, the nature of the Organization and of its operation would not seem to be such as to invite the inclusion in the Charter of any provision of this nature. If two member states are at variance concerning the correct interpretation of the Charter, they are of course free to submit the dispute to the International Court of Justice just as in the case of any other treaty. Similarly, it would always be open to the General Assembly or to the Security Council, in appropriate circumstances, to ask the International Court of Justice for an advisory opinion concerning the meaning of a provision of the Charter. Should the General Assembly or the Security Council prefer another course, an ad hoc committee of jurists might be set up to examine the question and report its views, or recourse might be had to a joint conference. In brief, the members or the organs of the Organization might have recourse to various expedients in order to obtain an appropriate interpretation. It would appear neither necessary nor desirable to list or to describe in the Charter the various possible expedients.

It is to be understood, of course, that if an interpretation made by any 
If the court is not empowered to give such a binding interpretation, how does the Charter get interpreted? President Winiarski makes it clear that, in his view, whenever a difference of opinion arises between the member states as to the meaning and obligation of the Charter, each member must make its own determination of the correct meaning of the Charter and is free to refuse to accept a contrary interpretation, or co-operate with any action taken pursuant to such a determination, regardless of the number of votes by which it is supported.77 This position, in effect, negates the existence of any obligation under the Charter. Such an interpretation is foreign to our understanding of any functioning governmental unit and, accordingly, we tend to reject any such description of the United Nations as unsatisfactory.

If it be assumed that the Charter does set down and recite the basis of agreement designed to cover and regulate future events, some machinery for the ascertainment and pronouncement of the application of the agreement in the Charter to those future events seems indispensable. ${ }^{78}$ One possibility is that each organ, acting independently, has conclusive ${ }^{70}$ authority to interpret

organ of the Organization or by a committee of jurists is not generally acceptable it will be without binding force. In such circumstances, or in cases where it is desired to establish an authoritative interpretation as a precedent for the future, it may be necessary to embody the interpretation in an amendment of the Charter. This may always ${ }^{*}$ be accomplished by recourse to the procedure provided for amendment.

Doc. No. 750.IV/2/B/1, 13 U.N. CoNf. INT'L ORg. Docs. 831-32 (1945). The last paragraph of this statement is especially significant.

77. Obviously, this too is the Soviet viewpoint. See, for instance, the following statement submitted to the court by the Soviet Union in the instant case:

It is precisely due to these considerations that the Soviet Delegation to the

United Nations voted against the resolutions of the General Assembly on the appropriations for the United Nations operations in the Congo and stated that, since those resolutions were in a direct contradiction with the most important provisions of the United Nations Charter, it would consider such resolutions illegitimate, and the Soviet Union would not deem itself committed in any extent by such unlawful resolutions.

U.S.S.R. WRITTEN STATEMENT 5.

78. On the problem of authority to interpret the Charter see Pollux, The Interpretation of the Charter, 23 BRIT. YB. INT'L L. 54 (1946).

79. The word "conclusive" here may lead to the drawing of conclusions from private or domestic law analogies. When such "conclusive" authority is found in our domestic law, the determination under that authority is expected to be followed by action in execution of such determination. Police and even military force may be used to secure such execution. It must be remembered in speaking of the United Nations as a governmental unit that no such process of execution is to be necessarily expected. Even though a source of "conclusive" interpretation of the Charter be identified, that interpretation may be frustrated by the political decision of an individual member to refuse to honor it. There seems to be some value, nevertheless, in speaking of authority, and even "conclusive" authority, within the United Nations to interpret the Charter. The Soviet position is unacceptable to us in that it assigns the right and power to interpret to each state acting individually. It has been our position that the Charter has a meaning that is objectively ascertainable. The difference between the Soviet position and ours is not one of asserting or denying the ultimate political power to refuse to honor an interpretation objectively ascertained. The difference in position is this: we would argue that a state should follow an objectively ascertained interpretation even though that state, in its own thinking, considered the interpretation to be erroneous. The Soviet position appears to accord such state the right to insist on its own interpretation and to ignore any other interpretation. Our position therefore posits the possibility of an objective 
the Charter in connection with its own performance, and that the decision of two-thirds of the delegates to the General Assembly that the expenses of the UNEF and ONUC operations are valid and apportionable is a conclusive determination of such validity. If this be true, then each organ may give a different construction to articles of the Charter. ${ }^{80}$ Conflicting interpretations would not necessarily impair United Nations practice since the overlap of function and interest of the various organs is by no means universal. As regards the most important overlap, that between the General Assembly and the Security Council, since the effect of the veto in the latter is frequently to prevent determination there, the tendency is to emphasize the paramountcy of the General Assembly's construction except in matters where the Security Council can and does act. As an operating description, then, the proposition that the General Assembly's construction is a conclusive and final one is not, from the viewpoint of theory, wholly unacceptable.

In spite of the failure in 1945 to appoint the court as conclusive interpreter of the Charter, most, if not all, of the judges in this case seemed to proceed on the basis that each organ is not the final and conclusive determiner for its own purposes. The majority opinion and most of the other judges agreed that the General Assembly must itself first pass on its own jurisdiction. The majority took the position that such a ruling has a presumption of validity. ${ }^{81}$ In this opinion, however, as in several earlier ones, the court clearly asserts its freedom to interpret the Charter differently from the Assembly. It may be inferred, therefore, that the court considers neither itself nor the General Assembly to be the single authoritative interpreter of the Charter.

The majority opinion, however, assumes that there can be an interpreta-

interpretation and emphasizes the importance of identifying the source of such interpretation.

80. Said Pollux:

The easiest, the most primitive, and the most unsatisfactory solution is to say that each individual Member has the right to decide for itself how to interpret the Charter. ... .

The next solution is that each organ of the United Nations should decide its own competence. . . . This is in practice what happens in the Constitution of many individual states. It ean hardly be said that the solution is ideal.

Pollux, supra note 78, at 56 \& 57 . It can probably now be said, however, that with respect to the United Nations this solution is the only practieable one available.

81. They appear to hypothesize the existence somewhere of a power or right of review of General Assembly determinations :

In determining whether the actual expenditures authorized constitute "expenses of the Organization within the meaning of Article 17, paragraph 2, of the Charter," the Court agrees that such expenditures must be tested by their relationship to the purposes of the United Nations in the sense that if an expenditure were made for a purpose which is not one of the purposes of the United Nations, it could not be considered an "expense of the Organization".

OpIn10N 167. They then formulate the presumption: "But when the Organization takes action which warrants the assertion that it was appropriate for the fulfilment of one of the stated purposes of the United Nations, the presumption is that such action is not ultra vires the Organization." Id. at 168. 
tion of the Charter binding upon the members. ${ }^{82}$ It is implicit in the opinion that such interpretation is achieved when the court adds its affirmative support to the position taken by a two-thirds vote of the Assembly. It may be that many Assembly delegates agree. It is no accident that the preamble to the resolution requesting the instant opinion states that the General Assembly,

Recognizing its need for authoritative legal guidance as to obligations of Member States under the Charter of the United Nations in the matter of financing the United Nations operations in the Congo and in the Middle East,

1. Decides to submit the following question to the International

Court of Justice for an advisory opinion....

It is interesting that the majority opinion, other than by explicitly stating that the opinion is advisory, neither expressly concurs nor denies that its opinion though advisory will be "authoritative."

Assuming that the Charter receives authoritative construction when the court and the General Assembly agree does not answer the question of what the authoritativeness of the court's decision would have been had it been contrary to the view of two-thirds of the General Assembly. As a practical matter, any opinion of the court, once sought, would be used in subsequent debate in the Assembly as substantive evidence on the issue of validity of the prior action. It is clear, in fact, that one of the purposes behind the reference to the court was not only to improve the payments position, but also to muster more affirmative votes behind the majority's decision that these expenses were apportionable. ${ }^{83} \mathrm{Had}$ the decision been negative, this too presumably would have been argued strongly in an attempt to persuade the Assembly or a two-thirds majority thereof not to reiterate or maintain its former position that these expenses were apportionable. Judge Koretsky's contention that a request for an opinion should not be answered if the opinion will be used for political purposes, ${ }^{84}$ i.e., persuasive purposes in subsequent debate, is not substantial; the Charter's provision for nonbinding, advisory opinions clearly envisions just such a situation.

If the General Assembly persisted in sustaining its prior position by a two-thirds vote despite a contrary decision of the International Court, a difficult problem would be posed concerning the theoretical legal position of dissenting states. Would the construction of the court be authoritative, would the Assembly's construction be authoritative, or would each dissenting state now be free to make its own interpretation on the grounds that the disagreement between the two organs demonstrated an absence of agreed

82. But see note 79 supra.

83. See note 30 supra and accompanying text.

84. "As the political aspect of the question posed to the Court is the prevailing one, the Court, to my mind, ought to avoid giving an answer to the question on the substance and ought not to find unwillingly that its opinion may be used as an instrument of political struggle." OPINION 254 (Koretsky, J., dissenting). 
meaning as to the obligation of the Charter? Certainly, in this situation, it would be much less embarrassing for dissenting states to assert their right to determine the meaning of the Charter on this point for themselves.

The question of authoritative construction is closely related to the possibility of sanctions. If a dissenting member persists in a private interpretation-either after the court and Assembly concur or after they disagreeit might, theoretically, be expelled or suspended pursuant to article 5 or article 6 . But, since article 5 speaks of suspension of a member "against which preventive or enforcement action has been taken," it seems necessarily implicit that expulsion under article 6 for "persistent violation of the principles of the Charter" would require at least that action or the occasion to take such action. Further, suspension or expulsion under these articles is academic, at least for any major power, because a Security Council recommendation, subject to veto, is required.

In contrast with the provisions of articles 5 and 6 , which require action by the Security Council, article 19 provides:

A Member of the United Nations which is in arrears in the payment of its financial contributions to the Organization shall have no vote in the General Assembly if the amount of its arrears equals or exceeds the amount of the contributions due from it for the preceding two full years. The General Assembly may, nevertheless, permit such a Member to vote if it is satisfied that the failure to pay is due to conditions beyond the control of the Member.

This might be read to mean that suspension from voting privilege is automatic unless an affirmative vote of the General Assembly certifies that nonpayment is due to such conditions beyond the control of the member. Because this sanction rests with the General Assembly, it could be asserted that, at least on matters touching contributions, the Assembly is competent to give an authoritative interpretation to the Charter. Recognition of the ultimate sanctioning power of the General Assembly may explain, in part, the heavy presumption of constitutionality given by the majority to the Assembly's determination of jurisdiction. Undoubtedly, that power also influenced the discussion concerning scope of review; the majority suggested, ${ }^{85}$ and Judge Spender specifically contended, ${ }^{86}$ that the costs of UNEF and ONUC operations are expenses within article $17(2)$ if incurred in execution of purposes of the United Nations, regardless of the propriety of the internal division of powers between separate organs of the United Nations.

The practical utility of the court's advice in influencing subsequent voting in the Assembly, however, led both the majority and most of the other judges to analyze and at least tentatively answer the issue of internal validity, the issue of the relative scope of authority of the General Assembly and the

85. See text accompanying note 40 supra.

86. See text accompanying note 48 supra. 
Security Council in matters of maintenance of the peace, and the authority of the General Assembly to make an obligatory assessment. These, after all, were and are the only serious relevant legal-type issues argued between the members in the General Assembly. ${ }^{87}$

\section{Probable Effects of the Decision}

\section{A. Persuasiveness of the Decision}

The effectiveness of the decision depends, in part, on the court's ability to withstand attack from its critics directed not only at this case but at the very concept of international adjudication. The Soviet Union, at the next session of the General Assembly, will doubtless claim, in line with Mr. Vyshinsky's comments ${ }^{88}$ on the advisory opinion on admission of new members, ${ }^{80}$ that there is no majority opinion and that a majority of the judges did not consider, did not deem it desirable to consider, or thought the court precluded from considering, the validity of the General Assembly resolutions. The majority were politically motivated, they will say, and so the whole opinion should be disregarded. It is unfortunate for the persuasiveness of the opinion that the French should have proposed their amendment to the question put and that the amendment should have been voted down. Eight judges, however, indicated their thought that UNEF and ONUC operations were validly conceived ${ }^{30}$ and only four judges indicated their opinion that these operations were invalid. Eight to four is an even better percentage than nine to five.

That two Latin American judges concluded that the expenses are not apportionable under article 17(2) may detract from the opinion's persuasiveness. It is interesting that one other Latin American judge and another civil law judge voted with the majority. None of the three civilian law judges who dissented could be impugned personally or on the basis of nationality as being a Soviet sympathizer. These three dissents serve then to underline what had long been apparent in the General Assembly-that the Charter could sustain different interpretations on this problem, and that the majority position was not the only one that an honest person could entertain. ${ }^{01}$ It is

87. It is of interest to note that the United States argued before the court that the validity of the resolutions was not in issue and, indeed, should not be covered: "The question submitted to the Court, as framed, is not directed to the validity of the underlying resolutions establishing UNEF and UNOC. The question can be answered without addressing those issues." U.S. WRITTEN STATEMENT 133.

88. See U.N. GeN. Ass. OfF. Rec. 3d Sess. Ad Hoc Pol. Comm. 67-71 (A/617, A/597, A/586, A/618) (1948).

89. Conditions of Admission of a State to Membership in the United Nations, [1948] I.C.J. Rep. 57.

90. Of the nine majority judges, it can be said that in addition to the five writing the majority opinion, Judges Spender, Fitzmaurice, and Morelli indicated their agreement that the resolutions were valid.

91. Insofar as the disagreement derives from uncertainty as to how the expenses should be apportioned, perhaps the most significant statement of the degree of disagree- 
interesting, and important, that perhaps in the last analysis the strength and persuasiveness of the opinion does tend to come down to an analysis of the nationality or background of the judges on both sides. Impartiality is the fundamental characteristic of a judge. But, in international matters, a belief or suspicion survives in some quarters that the degree of impartiality commonly attainable in domestic judges can not be expected on the International Court, ${ }^{92}$ because judges of the court can not divorce themselves from the national interests of their own governments. For this reason, the critics argue, international adjudication of such matters, seriously affecting the national interest of the member states, is not very profitable.

Much has been said in the past about the objectivity or lack thereof in the court and the basis of selection of the judges. ${ }^{93}$ A major decision is important evidence, therefore, on the subject of objectivity. It is difficult to regard as accident or coincidence the fact that President Winiarski, who comes from Poland, and the Russian, Judge Koretsky, dissented. It might also be expected that numbered among the majority or concurrences would be the United States judge (Jessup), the English judge (Fitzmaurice), and the Australian judge (Spender). The others in addition to Judge Jessup,

ment since 1956 is found in the Working Group of Fifteen's Report on the Examination of the Administrative and Budgetary Procedures of the United Nations, presented to the General Assembly:

It was not possible for the Working Group to find a sufficiently large area of agreement out of which it could present a set of recommendations for consideration by the General Assembly. The Working Group realizes that this report, because of the divergence of opinion among its members, has been unable to indicate any precise principles for finding a solution to the problem of financing peace-keeping operations undertaken by the United Nations.

U.N. GeN. Ass. Off. REc. 16th Sess., Annexes, Agenda Item No. 62, at 6 (A/4971) (1961).

92. For a recent review and refutation of statements alleging court partiality see Christol, The United States and Prospects for a World Rule of Law, 7 S.D.L. REv. 7, 31-36 (1962).

93. See, e.g., Briggs, Confidence, Apprehension and the International Cont of Justice, 54 American Soc'y InTernattonat L. Proceedings 25 (1960). Christol, The United States and Prospects for a World Rulle of Law, 7 S.D.L. REv. 7 (1962); Samore, National Origins v. Impartial Decisions: $A$ Study of World Court Holdings, 34 Chr.-Kent L. Rev. 193 (1956). See generally 2 Liacouras, The International Court of Justice: Materials on the Record of the Internattonal Court of Justice in Contentious Proceedings 449-532 (1962). Probably the best judgment on this subject is to be found in Lissitzyn, The InTERnational Court of Justice: Its Role in the Maintenance of International Peace and Security 49, 51-52, 55 (1951):

The impartiality of the members of an international tribunal is always somewhat suspect because national and traditional loyalties are felt to be among the strongest of emotions, and also because the political interests of particular states unavoidably enter into the selection of such members. . . . [The provisions for election of judges] . . have been criticized as not going far enough to make the selection of the judges independent of political influences; it has also been contended that the independence of the Court would be better safeguarded if its members were elected for life rather than for nine-year terms. Criticisms of this character appcar in part to be counsels of perfection. Every court is an organ of the community it serves, and as such cannot, and probably should not, escape all connection with the political processes of the community....

Despite the inclination shown by many members of the Court to take a favorable attitude toward the contentions and interests of their own states or 
for whom the majority opinion speaks, are Vice-President Alfaro (Panama) and Judges Badawi (United Arab Republic), Wellington Koo (China), and Tanaka (Japan). Judges Spiropoulos (Greece) and Morelli (Italy) also voted to answer the question put in the affirmative in addition to Judges Spender (Australia) and Fitzmaurice (United Kingdom). In addition to President Winiarski (Poland) and Judge Koretsky (Soviet Union), Judges Basdevant (France), Moreno Quintana (Argentina), and Bustamante y Rivero (Peru) dissented. In the vote in the General Assembly on December 20,1961, to apportion the ONUC and UNEF expenses in accordance with the regular schedule of contributions, the Soviet Union, Poland, and France voted "no," and the United Arab Republic and China abstained. The other countries having nationals on the court all voted "yes." The three judges who are nationals of the countries voting "no" also answered "no" on the court. Two judges, nationals of countries which abstained, voted "yes" on the court. And two judges, nationals of countries that voted "yes," voted "no" on the court.94

The split on the court falls far short of being completely on an EastWest axis even though the judges from the Soviet Union, Poland, the United Kingdom, and this country are on the appropriate sides. Regardless of the fact that all four judges have expressed their views with the utmost good faith and honesty, and regardless of the fact that their voting lineup may be explained by their legal training, which in turn affects their approach to construction of treaties and to the function and role of the United Nations, ${ }^{00}$

of states in similar positions, the Court apparently continues to enjoy a large measure of respect in the international community, perhaps because it is realized that the ideal of absolute impartiality is hardly ever attained even in the judicial tribunals of the best organized modern state.

94. The following table shows the arrearages in contributions to the ONUC and UNEF accounts of countries which presently have judges sitting on the International Court of Justice:
1. China
2. Japan
3. Panama
4. United Arab Republic (Egypt and Syria)
5. United States
6. Greece
7. Australia
8. United Kingdom
9. Italy
10. Poland
11. France
12. Argentina
13. Soviet Umon*
14. Peru

ONUC
$\$ 2,481,426$
7,925
63,398
45,567
-
$2,228,826$
678,553
$6,339,772$
219,911
$13,491,828$
21,793

UNEF
$\$ 3,972,703$
27,506
311,920
155,891
-
$\overline{-}$
$1,201,150$
837,934
$12,774,084$
92,582

* Without Ukrainian S.S.R. and Byelorussian S.S.R.

U.N. Secretartat, Statement on the Collection of Contrubutions as at 30 April 1962 (ST/ADM/SER.B/158) (1962). It is interesting to note that judges from the first nine states listed above voted "yes," while those from the remaining states voted "no," on the question of whether ONUC and UNEF costs were "expenses of the Organization."

95. That is to say, no judge can, or can be expected to, divorce himself from his 
states having genuine doubts about this issue may be apt to assume a measure of bias in their voting, and will discount the persuasiveness of their votes accordingly. In a considerable measure, then, the persuasiveness of the opinion for such states might be thought to rest on the views of judges from states more removed from the major East-West struggle. The provision for a fifteen judge court is in part a recognition of this type of problem.

If judges are, or are thought to be, biased in favor of particular national interests or concepts, it can be expected that the greater the diversity of their backgrounds, the wider the appeal of any given opinion will be-and the smaller the opportunity to attribute the result to bias. The present balance of the court, heavily dominated by judges in the western tradition of legal philosophy, may be subject to the criticism that it is not fully representative of the world's countries and legal systems, especially because of the total absence of representation from Africa and the under-representation from other parts of the world. ${ }^{96}$ Indeed, that total absence may explain in part the number of African votes against submitting the issue to the court.

\section{B. Effect on Contributions and General Assembly Decisions Concerning Apportionment}

Since the court's opinion is advisory and since the sanction lies with the General Assembly and the votes of its members, a serious danger exists in attributing too great an importance to the court's opinion. Its practical significance lies in influencing the subsequent voting and attitude of the member states toward the ONUC and UNEF expenses. Whether the opinion can be expected to produce more affirmative votes in support of maintenance of these operations and an improved payments position depends on the following question: are member states influenced in their international relations to any appreciable extent by legal-type arguments? Certainly most countries, including the United States, make argnments couched in, or taking advantage of, argumentation of this sort. It has been argued that Belgian interference in Katanga was in violation of the Charter, and that the invasion of Egypt was likewise such a violation. These arguments are appeals to the meaning of the Charter, to its interpretation, and such interpretation we familiarly class as a legal-type argument. The court concurs in labelling

background and training. Judge Levi Carneiro put this very neatly in his dissenting opinion in the Anglo-Iranian Oil Co. Case:

It is inevitable that everyone of us in this Court should retain sonie trace of his legal education and his former legal activities in his country of origin. This is inevitable, and even justified, because in its composition the Court is to be representative of "the nain forms of civilization and of the principal legal systems of the world" ....

[1952] I.C.J. Rep. 93, 161.

96. For a recent expression of this viewpoint see Anand, Role of the "New" AsianAfrican Conmtries in the Present International Legal Order, 56 AM. J. INT'L L. 383 (1962). The heavy representation of the civil law countries, which have two more representatives than the common law countries, has also been criticized. See Eagleton, Choice of Judges for the International Court of Justice, 47 AM. J. INT'L L. 462 (1953). 
the current issue of meaning of the Charter as a legal question. Some danger exists, however, in identifying the processes of international law with those of the domestic legal order-in which a determination of legality ordinarily controls action. Some popular identification of the two processes can be expected to follow from the use of the same language and characterization. But, on the international level, and in the United Nations, political motivation or evaluation may displace legal evaluation. Will a legal analysis of the Charter be a significant factor if and when the General Assembly votes on whether the Soviet delegation shall be permitted to continue to vote?

The dichotomy between legal and political questions is even more familiar in international affairs than it is in domestic law. The criteria for making the distinction are less clear and the consequences of making the distinction less certain. Once a determination is made that a particular question or facet of a question is "legal," and that a particular answer follows from the application of "legal" techniques, a political appraisal of the consequences may follow, partially or totally displacing the conclusion indicated by legal analysis. Since this is so, respect for, confidence in, and preoccupation with legal analysis tends to suffer. That "legal" and "political" are words describing polar tendencies in a continuous relationship, that they lack the precision of thought content upon which a clear characterization could be premised, has been commented on before. ${ }^{97}$ Law as a machinery for the implementation of politically-agreed policies and programs is more efficient as the certainty and content of those policies increases. Since the politically-agreed content of international law is relatively small, law is proportionately less efficient by comparison with domestic concepts. For these reasons it follows that in international politics, and in the United Nations, voting in no way inexorably follows legal analysis even where available. Reliance on expediency, however, becomes the more blatant and therefore the more embarrassing as the gap between law-motivated and expediency-motivated acts or votes widens. ${ }^{98}$ One of the more siguificant and novel tributes to the significance of this embarrassment is found in the decision made by the Soviet Union

97. See LaUterpachi, The Function of Law in the International Community 153-65 (1933). Professor Lissitzyn says:

All international disputes have both legal and political elements in varying proportions. The question whether a dispute is "legal" is a relative one, and the answer depends on the view taken by the contestants. If they all feel that the dispute can be effectively terminated by the application of legal standards, it is "legal," but if at least one of them does not share this attitude, the dispute must be regarded as primarily "political." This criterion also determines whether a "question" which has given rise to an international controversy is or is not "legal."

Lissitzyn, op. cit. supra note 93 , at 74 .

98. Witness the United States' apparent embarrassment over the U-2 flights; witness the Soviet embarrassment over suppression of the Hungarian revolt; witness the United Kingdom's embarrassment over Suez, and Indian embarrassment over invasion of $\mathrm{Hy}$ derabad and, subsequently, of the enclaved territories of Goa and Nagar-Aveli. 
and several satellites to participate in the written and oral proceedings before the court. ${ }^{99}$

A useful purpose is therefore served, with respect to many issues, by attempting to separate out those facets susceptible of legal analysis. Issues concerning the interpretation of treaty obligations have long been regarded as so susceptible; the utility of the legal analysis will or may still vary with the degree of political agreement fairly stated or necessarily implicit in the treaty. It is important to remember, then, that a substantial majority of delegations, in voting to refer this issue to the court, indicated their thinking that the settlement of the questions involved might be advanced by legal analysis. That the opinion of the court will create a measure of embarrassment for countries still denying the validity of the Congo and Middle East operations may be assumed. Whether, however, that embarrassment will be reflected in significant shifts of voting or increased contributions remains to be seen.

Statistics are significant here. For instance, on a recent vote to apportion some of these expenses in accordance with the standard formula, only sixty-nine states voted affirmatively, ten voted negatively, and eighteen abstained. ${ }^{100}$ The most significant votes, in terms of potential influence of the opinion, are, presumably, the abstentions. Another significant statistic is the current state of contributions to the cost of these two operations. ${ }^{101}$ It can be expected that states which are, themselves, in arrears will be less willing, for that reason if not for others, to condemn the failure of others to make any payment and to support the application of the sanction in article 19 that leads to loss of vote in the General Assembly.

\section{The Possibility of Suspension}

1. The procedure. Should the issue of suspension of a member state's right to vote be raised, some argument will probably develop as to whether any resolution will be required, whether a resolution if required should be worded positively or negatively, and whether such a resolution will require a two-thirds or only a simple majority for adoption. Article 19 is so drafted as to appear to bear the interpretation that the right to vote is lost automatically when the mathematical computation of arrearages of contributions so indicates. ${ }^{102}$ Moreover, it suggests that an affirmative vote of the Assem-

99. The Soviet Union, its two constituent republics Byelorussian S.S.R. and Ukrainian S.S.R., and Czechoslovakia, Bulgaria, and Romania, all submitted written statements in an attempt to persuade a majority of the court to give a negative answer to the question put. In addition, counsel for the Soviet Union delivered an oral statement.

100. See U.N. GeN. Ass. OfF. Rec. 16th Sess., Plenary 2-11 (A/PV.1044) (1961).

101. See note 15 supra.

102. See note 37 supra (text of article 19). Kelsen's discussion of this article suggests the possibility of the article being treated as containing an automatic sanction, but draws attention to the fact that someone has to make an authoritative decision that the state in question is in arrears for the prescribed period. The net result is that a decision of the Assembly necessarily is involved in a determination of this issue. See KELSEN, 
bly is required to prevent loss of such voting right. It seems possible, however, that, no matter how the question is raised, initially the vote of a simple majority will be involved. Conceivably, the issue could arise in many ways. The President of the General Assembly, on being informed that a state was sufficiently in arrears, might order the dropping of that state's name on the next roll-call vote. ${ }^{103}$ Such action would, no doubt, be challenged on a point of order. ${ }^{104}$ It has been suggested that the President could take the position that his decision is not subject to review by the Assembly. This suggestion, however, appears to ignore the political nature, the structure, and the parliamentary organization of the Assembly. It is more likely, therefore, that the President would either announce his ruling and put it to the Assembly for approval or disapproval, or else request the Assembly to indi-

The Law of the United Nations 717-19 (1950). That a resolution is required may not resolve the question of the form in which that resolution should be put or the majority by which it should be carried.

Though the San Francisco history contains little discussion of this article, it appears that the question whether the sanction might be automatic was raised in the Coordination Committee:

Mr. Robertson stated that there was a substantial difference between the words "waive the penalty" in the third sentence of the Committee text and the words "restore the privilege" [earlier formulations of article 19], substituted by the Secretariat, in that the latter implied that the penalty would automatieally be imposed. Mr. Jebb and Mr. Bailey agreed that the question of 'whether, in fact, the privilege to vote is withheld lies within the Assembly's discretion. To meet this difficulty, Messrs. Jebb and Robertson suggested that the words "may" restore the privilege of voting" be replaced by "may, nevertheless, permit such a member to vote".

Coordination Comm., Summary Report of Tenth Meeting, Doc. No. WD/206/CO/95, 17 U.N. CoNF. INT'L ORG. Docs. 50, 54 (1945). A tinge of doubt still remained however, in the Report of the Rapportentr of Commission II to the Plenary Session: "A member which has fallen two years in arrears on its financial obligations to the Organization, however, will not be allowed to vote except by special decision of the Assembly." Doc. No. 1177.II/18, 8 U.N. CoNr. INr'L ORG. Docs. 249 (1945).

103. Testifying recently before the United States Senate Committee on Foreign Relations, Secretary of State Dean Rusk was asked by Senator Aiken whether under article 19 a member's vote would be automatically lost by reason of arrearages. Secretary Rusk answered:

Article 19 of the Charter would seem to make that action automatic because the General Assembly is given permission to permit such a member to vote if it is satisfied that the failure to pay is due to conditions beyond the control of the member.

Now ... the Contributions Committee has before it each year the question of whether any recommendations are to be made with respect to article 19 . But the application of the Charter would seem to be automatic unless the Assembly took action otherwise.

Hearings on $S$. 2768 Before the Senate Committee on Foreign Relations, 87th Cong., 2d Sess. 53 (1962). See also Hearings on $S .2768$ Before the House Committee on Forcign Affairs, 87th Cong., 2d Sess. 26-27, 130-31 (1962) (remarks of Adlai Stevenson, United States Representative to the United Nations, and Harlan Cleveland, Assistant Secretary of State for International Organization Affairs).

104. It might be thought that the issue could be handled quite simply through the point of order procedure. Suppose, for instance, that after a vote on a resolution a delegate raised a point of order that the President had improperly included the vote of state $X$ in his tabulation of votes. Under rule 73, the President's ruling could be sustained by a simple majority vote. This procedure has not been used with respect to the question whether any particular resolution requires a two-thirds vote. Possibly, there might be serious objection to use of such procedure to settle this issue. See Kerley, Voting on Important Questions in the United Nations General Assembly, 53 AM. J. INT'I L. 324, 338-39 (1959). 
cate their instruction as to how he should rule. This process could be initiated either before or after the taking of a vote on some matter before the Assembly. In view of standing committee instructions, the problem might come up as one of substance rather than on a point of procedure. The Committee on Contributions is charged with reporting to the Assembly on the question of arrearages of sufficient amount to raise the application of article 19.105 The report of that committee might merely state the mathematical computations or might go further and make a recommendation. Whether that committee merely noted the facts, recommended that the right to vote be suspended, or that the right to vote be preserved in spite of the arrearages, could occasion a vote in the Assembly by way of action on the report. The formulation of the resolution might be important. Possibly, the pertinent draft resolution might provide "that $X$ state's right to vote be suspended," though, if article 19 were treated as requiring automatic suspension subject to revival of the right to vote, the resolution might be worded "that $X$ state's right to vote be not suspended." 'At this point it would become necessary to make a determination whether the majority required to pass either resolution were

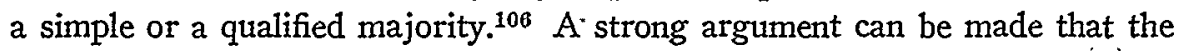
majority for suspension described in article 18 refers to a vote to suspend a member state under article 5 following a recommendation of the Security Council and not to the application of the sanction under article 19. Only a simple majority might therefore be required.

The long practice of the General Assembly suggests that, regardless of technical legal argument, many delegations would regard this issue as most serious, and essentially one of substance rather than procedure. On that ground, no matter in what form the question is raised or introduced, it might be expected that a simple majority would vote, under article 18 , to require a qualified majority to take any action on the report of the Committee on Contributions. ${ }^{107}$ For the same reason, it might be difficult to find

105. See Comm. on Contributions, Report, U.N. Gen. Ass. OfF. Rec. 16th Sess., Supp. No. 10, at $6(\mathrm{~A} / 4775)(1953)$.

106. Certain categories of questions are defined in article 18 as "important." The article also provides that a majority vote may determine "additional categories of questions ...." One of the questions specifically defined as "important" is "suspension of the rights and privileges of membership ..." Doubtless it would be argued that the resolution in issue involved suspension of a member and thus required a two-thirds majority. Both article 5 and article 19 provide for loss of voting privilege. Article 5 speaks of "suspension" including thereby loss of all privileges. Article 19 does not use the word "suspension" but merely states that a member state so in arrears "shall have no vote...." The strong argument is apparent, then, that the qualified majority for suspension described in article 18 refers to a vote under article 5 (following a recommendation of the Security Council) and not loss of vote under article 19. Conceivably, it might be argued that the resolution in issue comes under another category of questions prescribed as "important," namely "budgetary questions." It could be replied that suspension does not involve the budget but responsibility for failure to pay an allocated portion of that budget. On this construction the issue of suspension for arrcars could be settled by a simple majority vote.

107. A very high percentage of Assembly resolutions have been adopted by more than a two-thirds vote. RePERTORY of PRACTICE of UNITED NATIONS ORGANS 1955-1958, 
a simple majority to approve a procedural course whereby the sanction of article 19 would be sustained on the basis of a bare majority vote. Because of these problems, and because of the gravity of the issue, a number of delegations would perhaps prefer that the question be phrased affirmatively, that is, that the right to vote be suspended.

2. The probability of suspension. The majority opinion could, as Judge Moreno Quintana said, ${ }^{108}$ have consequences of great importance to the United Nations. If the opinion had the necessary persuasive power to permit the marshalling of a simple majority or a two-thirds vote to approve the invocation of the article 19 sanction, it could furnish the occasion of a showdown giving the Soviet Union the choice of following to some degree the operations administered by the Secretary-General or pulling out of the General Assembly and therefore, presumably, the United Nations as a whole. Although the possibility that the Soviet Union will be in arrears to the extent of two or more years of contributions appears very great ${ }^{100}$ in light of its

SuPP. No. 1, at 195 (U.N. Pub. Sales No. 1957.V.4/SUPP. 1/VOL. 1) (1958). Therefore, the question whether a qualified majority is reguired has seldom been argued.

108. OpINIon 239 (Moreno Quintana, J., dissenting).

109. It may be widely supposed that if the Sovict Union and the other countries who have denied all obligation to both the UNEF and ONUC programs do not make some payment in the near future they will be caught by the provisions of article 19. That is to say, their arrears will equal or exceed the amount of the contributions duc for the preceding two full years. A rough-and-ready calculation by the author, who denies he possesses any mathematieal or accounting ability at all, suggests that, so far as the Sovict Union is concerned, the applicability of article 19 is by no means near. This is because the opinion of the court appears to cut both ways. If ONUC and UNEF expenses are "expenses of the Organization" and apportionable as such, the apportionable amount for both programs must be taken into account in calculating the "contributions due ... for the preceding two full years." Clearly, the Soviet Union's share of these programs already exceeds the amount of its normal share of the budget for the two preceding years. But, when the share of these special programs is added to its regular share for the two preceding years, the Sovict Union's arrears do not equal the two-year total amount. This is because it is current on its regular budget payments. Sometime in the future it is probable that, if the ONUC expense's are ended, the Soviet Union's arrears under both programs might exceed its share of the regular budget for a given two-year period. Thus, Henry Cabot Lodge, appearing recently as a witness before the House Committee on Foreign Affairs, asserted that "the Russians are going to lose their vote in 1964," presumably, if no payments are made towards liquidation of their arrearages. Hearings on $S .2768$ Before the House Committee on Foreign Affairs, 87th Cong., 2d Sess. 163 (1962). The Sovict Union's current situation can be roughly illustrated, using for the purpose of illustration the financial figures published for the period ending December 31, 1961, as follows:

Soviet Union: General budget contribution 1960 1961

Share of UNEF expenses 1960 1961

Share of ONUC expenses 1960 1961

Total contributions due for preceding two years 
present attitude, the chance of suspension appears less certain. ${ }^{110}$ Many delegations believe that a major value of the United Nations is that it produces and supplies a forum for debate and argument in a controlled meeting, and constitutes the best opportunity for exchange, and, perhaps hopefully, partial modification of view or accommodation, between East and West. Moreover, the United Nations supplies equal opportunity for intervention in, and contribution to, that debate by states other than the major military powers. Delegations or states in any doubt about voting might be expected to weigh the consequent argument from expediency with that from legal interpretation.

\section{Prestige of the Court}

1. Internationally. If states persist in asserting the invalidity of the General Assembly apportionment of these expenses and if ultimately they are not, in terms of article 19, deprived of a vote, it is arguable that the prestige of the court will be damaged. Should the opinion of the court, however, have some effect in persuading more states to vote in favor of apportionment and to contribute either for the first time or in greater amounts, it will have proved an instrument of value in the politics of the United Nations, and expectably it will be drawn into other issues of importance. Certainly the court can not increase its influence if it never becomes involved in major issues or disputes.

The past history of General Assembly conduct indicates a hesitancy to

$\begin{array}{lr}\text { UNEF expenses } & 12,774,084 \\ \text { ONUC expenses } & 20,088,253 \\ \text { Total arrears } & \$ 34,431,180\end{array}$

U.N. Secretariat, Statement on the Collection of Contributions as of 30 Aprir. 1962 (ST/ADM/SER.B/158) (1962). The Soviet Union's arrears, then, do not exceed the contributions due for the two preceding years. It should be explained that the preceding calculations assume several definitions of importance which might well be contested; e.g., the exact scope of "contributions" in article 19.

One state which might be caught by the rule if it made no payment since December 31,1961 to either of the special programs or towards its regular budget contribution is China. This is due to the fact that as of December 31, 1961 it was in arrears with respect to its regular budget contribution not only for 1961 but also for 1960 . Financial Report and Acconnts for the Year Ended 31 December 1961 and Report of the Board of Auditors, U.N. GEN. Ass. OFF. Rec. 17th Sess., Supp. No. 6 (A/5206) (1962); Financial Report and Acconnts for the Year Ended 31 December 1960 and Report of the Board of Auditors, U.N. Gen. Ass. OfF. Rec. 16th Sess., Supp. No. 6 (A/4777) (1961).

110. Although a case for application of the article 19 sanction may not arise for several years, continued mass refusal to pay may soon necessitate abandonment of the police action or else require alternate financing from voluntary contribution. The authorization to float United Nations bonds may be thought to be a way of bringing the cost of these actions into the regular budget amortized over a period of years. The skeptic will remain convinced that the Soviet Union and its associated states will continue to refuse to contribute regardless of how the costs appear-amortized or any other way-in the budget. Since they have a fondness for proverbs or similar phrases, they will no doubt say: "a rose by any other name...." Incidentally, this opinion produces two new Soviet sayings or proverbs of some note: "it has been said that you cannot leave one word out of a song," OPINION 272 (Koretsky, J., dissenting); and "people say that you cannot have two coachmen in the driver's seat" Ibid. In all probability, the strongest Soviet effort designed to defeat or impair such continued police action will again take the form of attempting to put three coachmen in the driver's seat, that is, of trying to impose the "troika" on the office of Secretary-General. 
involve the court in issues of as grave significance as this present one. ${ }^{111}$ Although the issue of admission of new members to the United Nationson which the United States and Soviet Union had clearly divergent positions-was twice submitted for advisory opinions, ${ }^{112}$ on other issues between East and West, the General Assembly has been much more cautious about involving the court. ${ }^{113}$ This restraint may have been attributable to a feeling that when major political problems are concerned the opinion of the court if given would not produce significant reaction or change of position on the part of the member states. The decision on this occasion to refer the dispute to the court could be a turning point for the court. It can be doubted that a number of delegations would have pressed and voted for a reference to the court had they not been persuaded that some use could be made of its decision in subsequent debate. Their forecast or expectation will be on trial.

2. Domestically. The decisions of the court have not, at least before this opinion, had great significance for the vested interests of this country. ${ }^{\mathbf{1 1 4}}$ Regardless of the court's caveat, if there be one intended, ${ }^{115}$ the decision will be understood as a ruling that the contributions as apportioned are obligatory on the member states. Should this opinion not be followed, or circumvented in one way or another in subsequent business of the General Assembly, an adverse reaction to the court and to the court's significance can be anticipated. The failure of the court's opinion might reflect not only on the court's prestige but also upon that of the United Nations itself.

Should the Soviet Union and other countries maintain delinquency with regard to their apportioned shares of expenses for UNEF and ONUC operations, the General Assembly will be forced either to abandon its expensive peace-keeping operations or to adopt the dissenting judges' suggestion of contribution only by those approving of measures taken. Cessation would tend to establish the fact that the United Nations can not operate a substantial police or peace force of this sort even when the trouble is between relatively small and militarily powerless groups.

111. See U.N. Gen. Ass. Off. Rec. 2d Sess., Plenary 859 (A/459, A/459/Corr. 1) (1947), discussing the Sixth Committee's Report on the Need for Greater Use by the United Nations and its Organs of the International Court of Justice.

112. It can be doubted whether the court's two opinions given therein added much pressure to that already exerted on the Soviet Union not to block many additional states from joining. The supposition that sheer horsetrading, rather than the influence of those two opinions, brought about a break in the deadlock is at least superficially attractive.

113. The question of Chinese representation, for instance, has not been presented to the court, though it might be thought to contain a number of legal issues, including the construction of Charter articles. A draft resolution introduced to refer the Palestine problem, or at least some aspects of it, to the court, was defeated. See U.N. GEN. Ass. OFF. REc. 2d Sess., Ad Hoc Comm. on Palestine Question 299-301 (A/AC.14/32) (1947).

114. The Interhande! Case, [1959] I.C.J. Rep. 6, could have assumed considerable importance, but was dismissed, on preliminary objection, on the grounds of nonexhaustion of local remedies.

It is indeed surprising that the Connally Amendment provoked such a sustained and hotly contested debate. See Christol, supra note 93.

115. See text accompanying notes 35-37 supra. 
It is patently clear that such an eventuality would seriously diminish respect in this country for the United Nations.

The other alternative, voluntary financing-no doubt primarily by the United States-would also cause disenchantment. Congress would be unenthusiastic over the idea of paying by voluntary gift or contribution to the United Nations a sum which the court has explicitly described as the legal obligation of other countries. It may need even stronger persuasion of the strategic value to us of preventing disorder of this type through United Nations intervention.

Conceivably, adoption of the principles of this decision could operate to the disadvantage of the United States. As interpreted by the majority, the Charter authorizes the General Assembly to incur expense, upon the concurrence of a two-thirds vote, for any program consistent with the "purposes" of the United Nations. From a purely theoretical standpoint, vast programs for the economic development of underdeveloped countries could be undertaken at United Nations expense. The United States could then be invited to pay its allotted share whether it had voted for the programs in question or not. Such an eventuality is not a practical possibility, however; the United States has sufficient political influence to foreclose such a vote. Were such a vote taken, this country could refuse to pay, and were voting rights suspended, the United States might feel forced to withdraw from the Organization.

When the present decision is read in light of political realities, then, it appears sound. In part, that it may seem so is a fundamental commentary on the fact that we do not have a world government. If the organization were tighter and the cost of refusal to honor its decisions higher, we might have graver doubts about the kind of blank check that this opinion gives the General Assembly, and might place a higher value on the restrictions which Judge Fitzmaurice saw necessary to read into the Assembly's freedom to spend and tax. 